\title{
Effect of Exercise on Cardiac Tissue Oxidative and Inflammatory Mediators in Chronic Kidney Disease
}

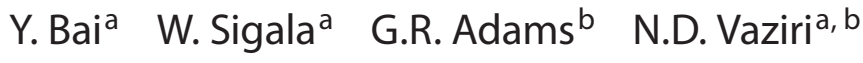 \\ ${ }^{a}$ Division of Nephrology and Hypertension and ${ }^{b}$ Department of Physiology and Biophysics, \\ University of California Irvine, Irvine, Calif., USA
}

\section{Key Words}

Cardiovascular disease • Oxidative stress • Inflammation •

Renin-angiotensin system $\cdot$ Hypertension

\begin{abstract}
Background: Chronic renal failure (CRF) results in diminished physical activity and increased risk of cardiovascular disease (CVD). CVD risk factors are raised by sedentary life style and ameliorated by physical fitness in the general population. Accordingly, exercise improves hypertension, endothelial dysfunction, insulin resistance, dyslipidemia, inflammation and oxidative stress in high-risk populations. This study was designed to explore the effect of exercise on oxidative and inflammatory mediators in the left ventricle (LV) of CRF rats. Methods and Results: One week after 5/6 nephrectomy female rats were housed in either regular cages or cages equipped with running wheels for 4 weeks. Shamoperated rats housed in regular cages served as controls. Sedentary CRF rats exhibited azotemia, hypertension, anemia, oxidative stress, activation of NF- $\kappa B$ and upregulations of reactive oxygen species-generating enzyme, $\mathrm{NAD}(\mathrm{P}) \mathrm{H}$ oxidase, MCP-1, cyclooxygenase-2 (COX-2), and PAI-1 in LV. The $\mathrm{CRF}$ rats assigned to the exercise group ran $6.8 \pm 0.7 \mathrm{~km} /$ day and $72 \pm 8 \mathrm{~min} /$ day. Voluntary exercise reversed NF- $\mathrm{KB}$ activation and lowered NAD(P)H oxidase, PAI-1, MCP-1 and COX-2 abundance, increased LV mass by raising myofibrillar
\end{abstract}

\section{KARGER}

() 2008 S. Karger AG, Base

Fax +41613061234 E-Mail karger@karger.ch www.karger.com www.karger.com/ajn proteins and ameliorated anemia without affecting renal function or arterial pressure. Conclusions: CRF resulted in upregulation of prooxidant/proinflammatory pathways in LV. These changes were ameliorated by exercise, which indicates the potential cardiovascular benefit of exercise in renal insufficiency.

Copyright $\odot 2008$ S. Karger AG, Basel

\section{Introduction}

Chronic renal failure (CRF) is associated with a significant reduction of exercise capacity and a marked increase in the risk of atherosclerosis and cardiovascular disease (CVD) [1,2]. Atherosclerosis and CVD in CRF are associated with and largely driven by oxidative stress [3-5], inflammation [6,7], reduced nitric oxide (NO) availability $[8,9]$, upregulation of tissue renin-angiotensin system [10], hypertension (HTN), and dyslipidemia [11].

Sedentary life style and poor physical fitness heighten, whereas physical fitness lowers, the risk of atherosclerotic CVD in the general population $[12,13]$. Moreover, exercise as an intervention improves risk factors for CVD [14-16]. The favorable cardiovascular effects of physical activity are particularly pronounced in individuals with CVD risk factors such as insulin resistance and obesity.

N.D. Vaziri, MD, MACP

Division of Nephrology and Hypertension, UCI Medical Center

101 The City Drive, Bldg 53 Rm 125 Rt 81

Orange, CA 92868 (USA)

Tel. +1 714456 5142, Fax +1 714456 6034, E-Mail ndvaziri@uci.edu 
Indeed, increased levels of fitness appear to have a greater protective effect against CVD in obese than in lean populations [12].

Physical exercise can lower the risk of CVD by a number of mechanisms. For instance, regular exercise can lower blood pressure in hypertensive patients [17]. Moreover, exercise training can significantly improve endothelial function in patients with congestive heart failure and type 2 diabetes $[18,19]$. In addition, exercise alone or in combination with dietary modifications can ameliorate lipid disorders, insulin resistance, inflammation and oxidative stress in high-risk populations $[12,15,16,20$, 21]. Long-term exercise training has been shown to improve endothelial function, increase NO availability and attenuate HTN in patients with CVD $[22,23]$. The favorable effect of long-term exercise on endothelial function appears to be, in part, due to reduction of reactive oxygen species (ROS) production and thus enhanced NO availability in the cardiovascular tissues [24].

For a variety of medical and psychological reasons, physical activity is greatly reduced in patients with advanced chronic kidney disease. Given the deleterious effects of sedentary life style and beneficial effects of physical activity on cardiovascular system, we hypothesized that exercise training may attenuate the expression of mediators of oxidative stress and inflammation in the heart of CRF animals.

\section{Methods}

\section{Study Groups}

Female Sprague-Dawley rats with an average body weight of 224 g (Harlan Sprague Dawley, Indianapolis, Ind., USA) were used in this study. Animals were housed in a climate-controlled vivarium with 12-hour light and dark cycles and were fed a standard laboratory diet (Purina Rat Chow; Purina Mills, Brentwood, Mo., USA) and water ad libitum. All rats were initially placed in wheel-equipped cages (with the capability to record the distance and duration of running exercise) for 7 days in order to become familiar with the running exercise. They were then returned to standard cages and randomly assigned to the CRF and sham-operated control groups. The CRF group underwent 5/6 nephrectomy by surgical resection of the upper and lower thirds of the left kidney followed by right nephrectomy 4 days later. The control group underwent sham operations. The procedures were carried out under general anesthesia (pentobarbital sodium $50 \mathrm{mg} / \mathrm{kg}$ i.p.) using strict hemostasis and aseptic techniques. The nephrectomy procedures were accomplished via dorsal incisions as described previously [25]. After a 7-day recuperation period the CRF animals were randomized to the exercise and sedentary subgroups. The animals assigned to the exercise group were placed in the wheel-equipped cages whereas those assigned to the sedentary subgroups were housed in the standard laboratory cages.
Only 1 animal was placed in each standard or wheel-equipped cage throughout the study period. The animals were observed for 4 weeks. At the conclusion of the study period, the animals were placed in individual metabolic cages for a timed urine collection. The animals were then anesthetized (pentobarbital $50 \mathrm{mg} / \mathrm{kg}$ i.p.) and euthanized by exsanguinations using cardiac puncture. The heart was immediately removed, cleaned with PBS, snap-frozen in liquid nitrogen, and stored at $-80^{\circ} \mathrm{C}$ until processed.

Plasma urea nitrogen, creatinine concentrations, and creatinine clearance were determined using standard laboratory procedures. The experimental protocol employed in the study was approved by the Institutional Animal Care and Use Committee of the University of California, Irvine.

\section{Measurement of Arterial Pressure}

Arterial pressure was determined by tail plethysmography (Harvard Apparatus, Natick, Mass., USA) as described previously [26]. Briefly, the conscious animal was placed in a restrainer and permitted to rest for $10-15 \mathrm{~min}$. The cuff was then placed on the tail and was inflated and released several times to condition the animal to the procedure. After stabilization, blood pressure was measured 3 times, and the average of these values was used.

Measurements of Creatinine and Urea Concentrations

Creatinine concentration was determined with the use of the DICT-500 kit purchased from BioAssay Systems (Hayward, Calif., USA). This colorimetric assay is based on the kinetic Jaffe reaction. Urea concentration was measured with the DIUR-500 kit (BioAssay Systems) utilizing the $o$-phthaldialdehyde reagent.

\section{Tissue Preparation}

The left ventricle (LV) was separated and homogenized in $10 \mathrm{mM}$ HEPES buffer, $\mathrm{pH}$ 7.4, containing $320 \mathrm{~mm}$ sucrose, $1 \mathrm{mM}$ EDTA, $1 \mathrm{mM}$ DTT, $10 \mathrm{mg} / \mathrm{ml}$ leupeptin, $2 \mathrm{mg} / \mathrm{ml}$ aprotinin, and $1 \mu \mathrm{M}$ phenylmethylsulfonyl fluoride at $0-4^{\circ} \mathrm{C}$. A Polytron tissue mixing and blending device was used to blend the tissue into a smooth homogenate. Homogenates were centrifuged at $12,000 \mathrm{~g}$ for $10 \mathrm{~min}$ at $4^{\circ} \mathrm{C}$ to precipitate tissue debris. The supernatant was used to perform the Western analyses. Total protein concentration was determined by Bradford assay with the use of a Bio-Rad kit (Bio-Rad Laboratories, Hercules, Calif., USA).

\section{Western Blot Analyses}

Protein abundance of cyclooxygenase-2 (COX-2), MCP-1, PAI-1, and $\mathrm{NAD}(\mathrm{P}) \mathrm{H}$ oxidase subunits (gp91 ${ }^{\text {phox }}$, NOX-4, and p22 $2^{\text {phox }}$ ) were measured by Western blot analysis as described in our earlier studies [27]. Polyclonal antibody against COX-2 was purchased from Cayman Chemical (Ann Arbor, Mich., USA). Anti-MCP-1 antibody was purchased from Abcam (Cambridge, Mass., USA). PAI-1 antibody was purchased from BD Biosciences (San Diego, Calif., USA). The polyclonal antibody against gp91 ${ }^{\text {phox }}$ was purchased from Upstate (Lake Placid, N.Y., USA). The anti-p22 antibody was a generous gift from Dr. A.J. Jesaitis (Montana State University). Western blot blue staining (Perkin Elmer, Boston, Mass., USA) was used to verify the uniformity of protein load and transfer efficiency across the test samples. Experiments failing this test were discarded. Peroxidase-conjugated immunopure goat anti-rabbit IgG $(\mathrm{H}+\mathrm{L}$, Pierce Biotechnology, Rockford, Ill., USA) and sheep anti-mouse IgG, HRP linked (Amersham ECL, GE Healthcare, Piscataway, N.J., USA) were used as 

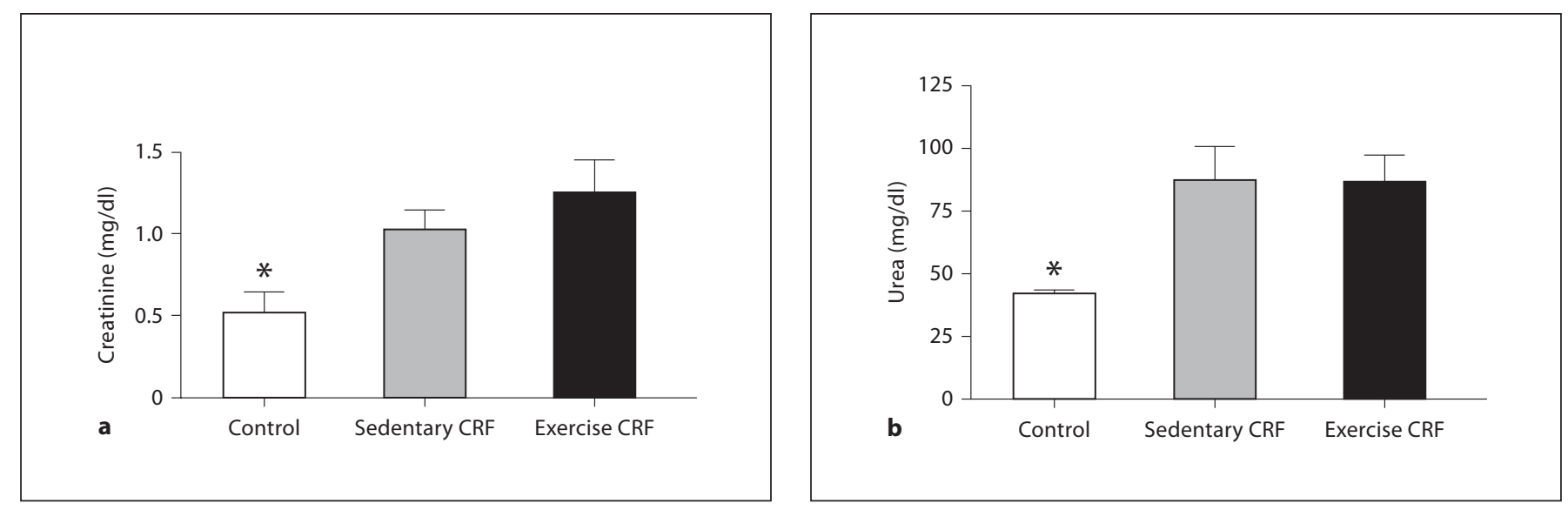

Fig. 1. Plasma creatinine (a) and urea (b) concentrations in sham-operated (control) group, 5/6 nephrectomized rats housed in regular cages (sedentary CRF) and 5/6 nephrectomized rats housed in cages equipped with running wheels (exercise CRF group) for 4 weeks. ${ }^{*} \mathrm{p}<0.05$, CRF versus other groups ( $\mathrm{n}=6$ animals in each subgroup).

Table 1. Body weight, muscle mass, blood hemoglobin concentration, left ventricular mass and myofibrillar protein levels in sham-operated control rats, 5/6 nephrectomized rats housed in regular cages (CRF) and 5/6 nephrectomized rats housed in cages equipped with running wheels (CRF exercise)

\begin{tabular}{|c|c|c|c|c|c|}
\hline \multirow[t]{2}{*}{ Groups } & \multirow{2}{*}{$\begin{array}{l}\text { Body } \\
\text { mass, g }\end{array}$} & \multirow{2}{*}{$\begin{array}{l}\text { Medial gastrocnemius } \\
\text { muscle mass } \\
\mathrm{mg} \cdot \mathrm{g} \text { body } \text { mass }^{-1}\end{array}$} & \multirow[t]{2}{*}{ Hemoglobin } & \multicolumn{2}{|l|}{ Left ventricular } \\
\hline & & & & $\begin{array}{l}\text { mass } \\
\mathrm{mg} \cdot \mathrm{g} \text { body } \mathrm{mass}^{-1}\end{array}$ & $\begin{array}{l}\text { myofibrillar protein } \\
\mathrm{mg} \cdot \mathrm{g} \text { muscle } \mathrm{e}^{-1}\end{array}$ \\
\hline Control & $274 \pm 9$ & $2.39 \pm 0.07$ & $17.5 \pm 0.3$ & $2.16 \pm 0.03$ & $78.0 \pm 3.1$ \\
\hline $\mathrm{CRF}$ & $260 \pm 10$ & $2.38 \pm 0.06$ & $14.0 \pm 0.3^{*}$ & $2.38 \pm 0.08$ & $85.2 \pm 3.6$ \\
\hline CRF exercise & $250 \pm 5$ & $2.54 \pm 0.07$ & $17.9 \pm 2$ & $2.99 \pm 0.06^{*,+}$ & $79.6 \pm 3.4$ \\
\hline
\end{tabular}

${ }^{*} \mathrm{p}<0.05$ versus control; ${ }^{+} \mathrm{p}<0.05$ versus CRF.

secondary antibodies and diluted in 5\% nonfat milk at 1-10,000. $\mathrm{NF}-\kappa \mathrm{B}$ activation was assessed by measuring tissue phospho-ІкB abundance by Western analysis using a polyclonal rabbit antibody purchased from Cell Signaling Technology (Denver, Colo., USA). The monoclonal antibody against GAPDH was purchased from Genetex (San Antonio, Tex., USA). Optical densities of the target protein bands were determined by a laser densitometer (Molecular Dynamics, Sunnyvale, Calif., USA) quantified with Image Quant 5.2 and normalized against those of GAPDH.

\section{Myofibrillar Protein Determination}

Myofibrillar protein was determined as previously described [28]. Briefly, muscle samples were weighed, then homogenized in approximately $20 \mathrm{vol}$ of an ice-cold solution containing $250 \mathrm{~mm}$ sucrose, $100 \mathrm{mM} \mathrm{KCl}$, and $5 \mathrm{~mm}$ EDTA. The homogenate was washed (suspended, then centrifuged at $1,000 \mathrm{~g}$ for $10 \mathrm{~min}$ ) successively in three solutions: (1) $250 \mathrm{mM}$ sucrose, $100 \mathrm{mM} \mathrm{KCl}, 20$ mM imidazole, and 5 mM EDTA (pH 6.8); (2) 0.5\% Triton X and $175 \mathrm{mM} \mathrm{KCl}$ (pH 6.8), and (3) $150 \mathrm{mM} \mathrm{KCl}$ and $20 \mathrm{~mm}$ imidazole ( $\mathrm{pH}$ 7.0). Each wash was repeated 3 times. The final pellet was re- suspended in $10 \mathrm{vol}$ of $150 \mathrm{mM} \mathrm{KCl}$ (relative to extracted muscle weight). The myofibrillar protein concentration of this final solution was determined using the biuret method.

\section{Data Analysis}

Analysis of variance was used in statistical evaluation of the data using GraphPad Prism version 5.0. Data are given as mean \pm SEM. $\mathrm{p}<0.05$ was considered significant.

\section{Results}

\section{General Data}

Data are shown in table 1 and figure 1. Body weight obtained at the conclusion of the study was significantly lower in the CRF rats than in the control animals. The $\mathrm{CRF}$ rats assigned to the exercise group ran $6.8 \pm 0.7$ $\mathrm{km} /$ day and $72 \pm 8 \mathrm{~min} /$ day. The intensity and duration 

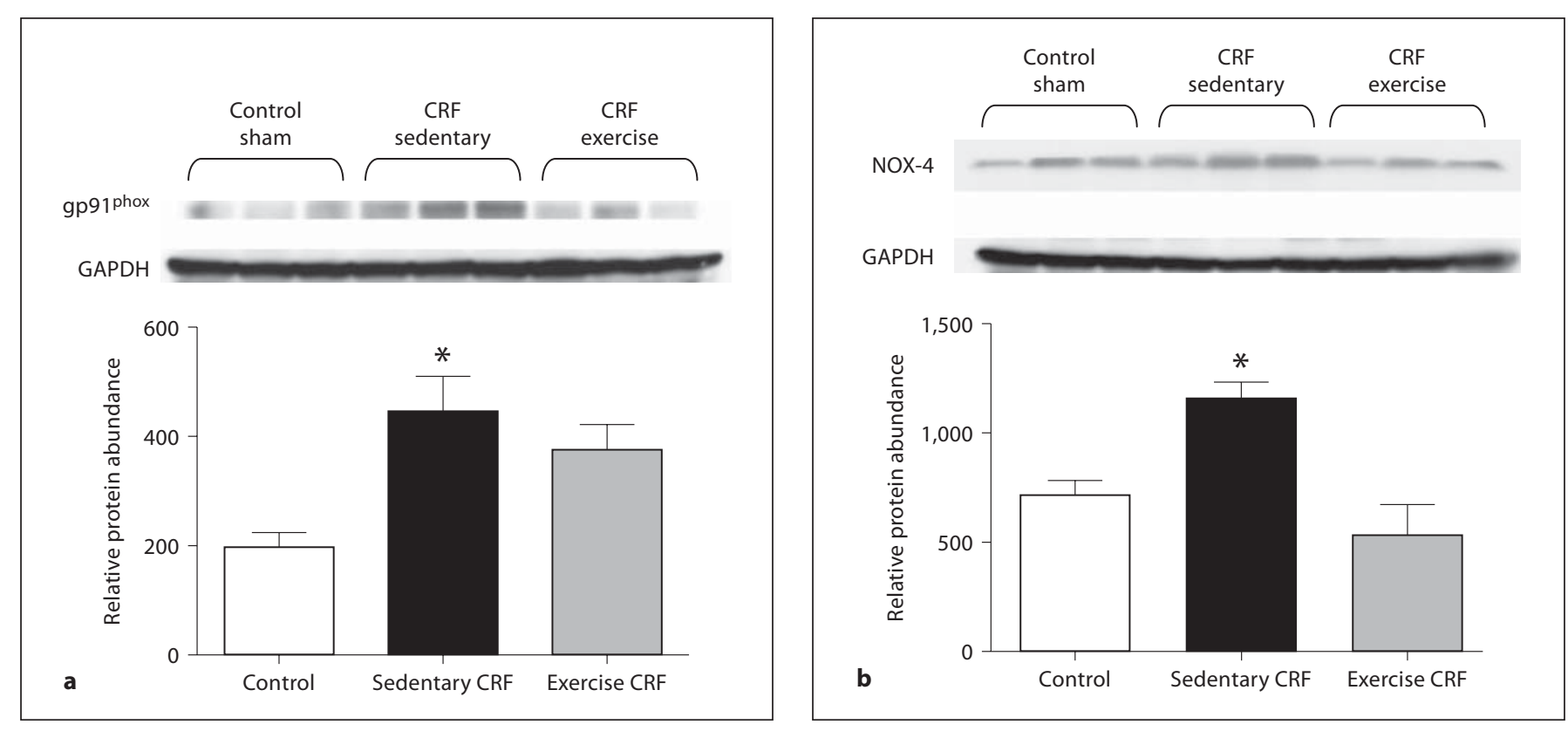

Fig. 2. Representative Western blots and group data depicting gp91 ${ }^{\text {phox }}(\mathbf{a})$ and NOX-4 (b) abundance in the LV of sham-operated (control) group, 5/6 nephrectomized rats housed in regular cages (sedentary CRF) and 5/6 nephrectomized rats housed in cages equipped with running wheels (exercise CRF group) for 4 weeks. ${ }^{*} \mathrm{p}<$ 0.05 , sedentary CRF versus other groups ( $n=5-6$ animals in each subgroup).

of voluntary exercise in CRF animals were not significantly different from those observed prior to $5 / 6$ nephrectomy. The exercise regimen resulted in a mild reduction of body weight in the study animals. However, the reduction in body weight was associated with a rise in the muscle mass/body weight ratio. As expected, serum creatinine and urea nitrogen concentrations were significantly elevated in the CRF group and were not affected by exercise training (fig. 1). Blood hemoglobin concentration was significantly reduced in the CRF rats, reflecting anemia of chronic kidney disease (table 1). The CRF-induced anemia was significantly ameliorated in the exercise group. Arterial blood pressure was significantly higher in CRF rats than in the sham-operated animals and was not significantly altered by the exercise regimen as shown in a previous study [28].

\section{Size and Composition Data}

CRF animals studied 5 weeks after 5/6 nephrectomy did not show significant changes in either the mass, total protein content or myofibrillar protein content of the heart. However, voluntary exercise resulted in a $26 \%$ increase in both cardiac and LV mass. The observed LV hypertrophy was accompanied by a proportional increase in myofibrillar protein content. Consequently, concen-

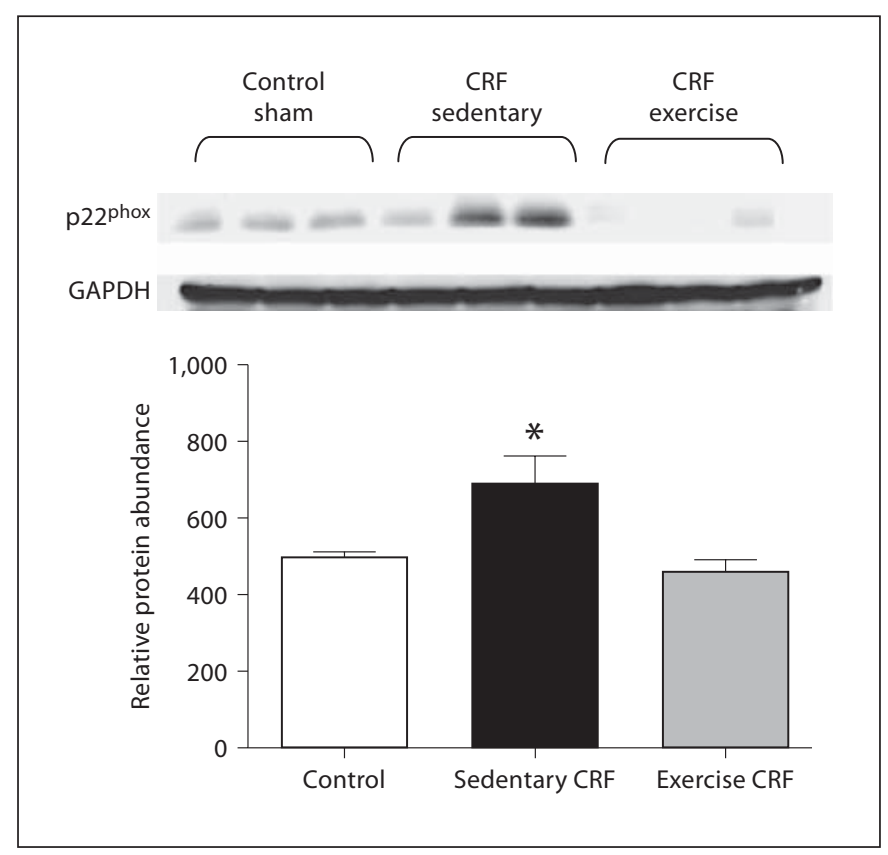

Fig. 3. Representative Western blots and group data depicting p22 $2^{\text {phox }}$ abundance in the LV of sham-operated (control) group, 5/6 nephrectomized rats housed in regular cages (sedentary CRF) and $5 / 6$ nephrectomized rats housed in cages equipped with running wheels (exercise CRF group) for 4 weeks. ${ }^{*} \mathrm{p}<0.05$, sedentary CRF versus other groups ( $n=5-6$ animals in each subgroup). 

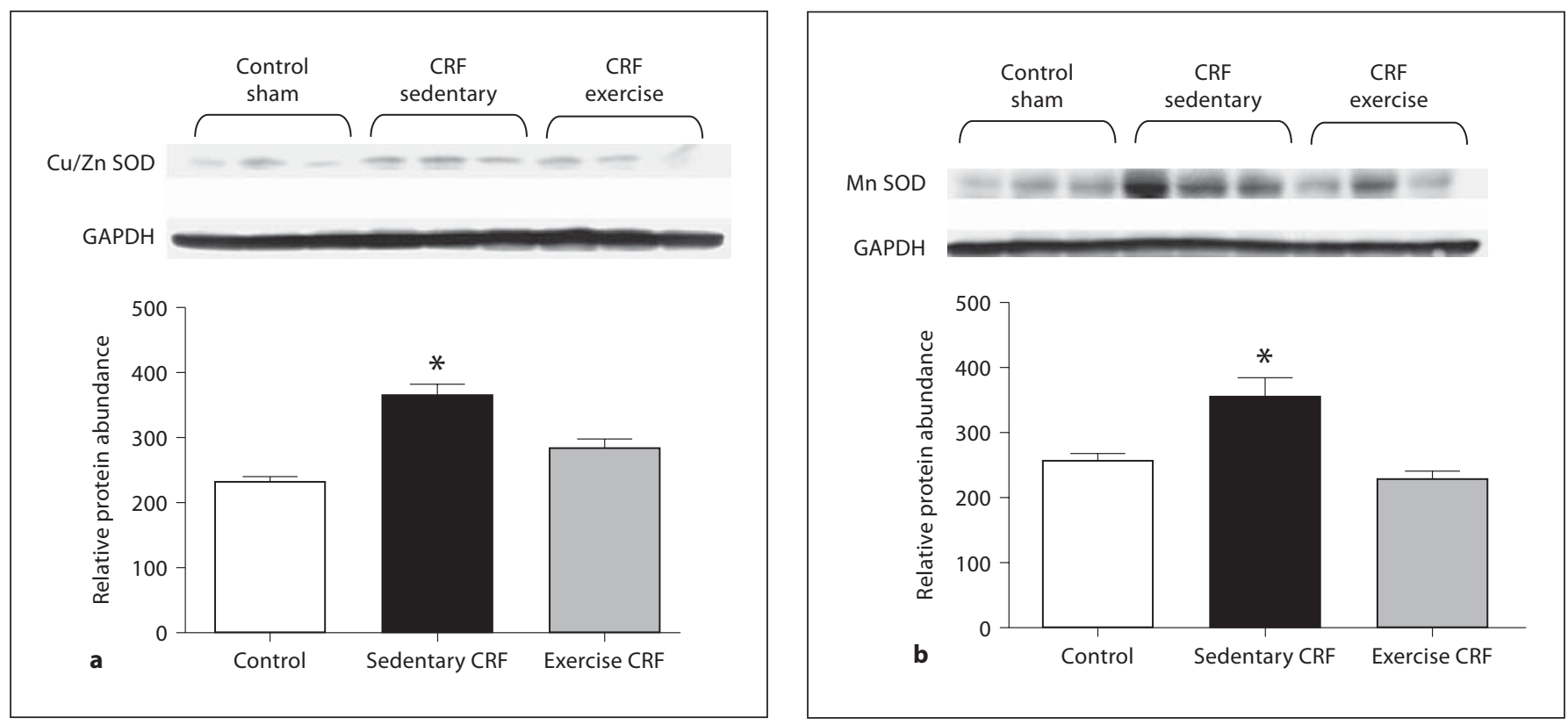

Fig. 4. Representative Western blots and group data depicting CuZn SOD (a) and Mn SOD (b) abundance in the LV of sham-operated (control) group, 5/6 nephrectomized rats housed in regular cages (sedentary CRF) and 5/6 nephrectomized rats housed in cages equipped with running wheels (exercise CRF group) for 4 weeks. ${ }^{*} \mathrm{p}<0.05$, sedentary CRF versus other groups ( $\mathrm{n}=6$ animals in each subgroup).

tration of contractile proteins remained normal (table 1). This proportional increase in contractile elements indicates that the observed hypertrophy represents the functional adaptation to increased demand imposed by exercise and as such is akin to 'athlete's heart' $[29,30]$ as opposed to pathological hypertrophy involving myocardial fibrosis $[31,32]$.

\section{NAD $(P) H$ Oxidase Data}

Data are shown in figure 3. Compared with the control rats, the CRF group showed marked upregulations of gp91 phox and NOX-4 and a mild upregulation of p22 $2^{\text {phox }}$ abundance in the cardiac tissue. Voluntary exercise resulted in the reversal of upregulation of these $\mathrm{NAD}(\mathrm{P}) \mathrm{H}$ oxidase subunits in the CRF rats.

\section{Antioxidant Enzyme Data}

Data are shown in figure 4. Upregulation of the superoxide-generating enzyme, $\mathrm{NAD}(\mathrm{P}) \mathrm{H}$ oxidase, in sedentary CRF rats was accompanied by compensatory upregulations of cytoplasmic (CuZn SOD) and mitochondrial (Mn SOD) superoxide dismutase. Voluntary exercise resulted in normalization of cardiac tissue CuZn SOD and Mn SOD abundance.

Cardiac Effect of Exercise in Chronic Kidney Disease

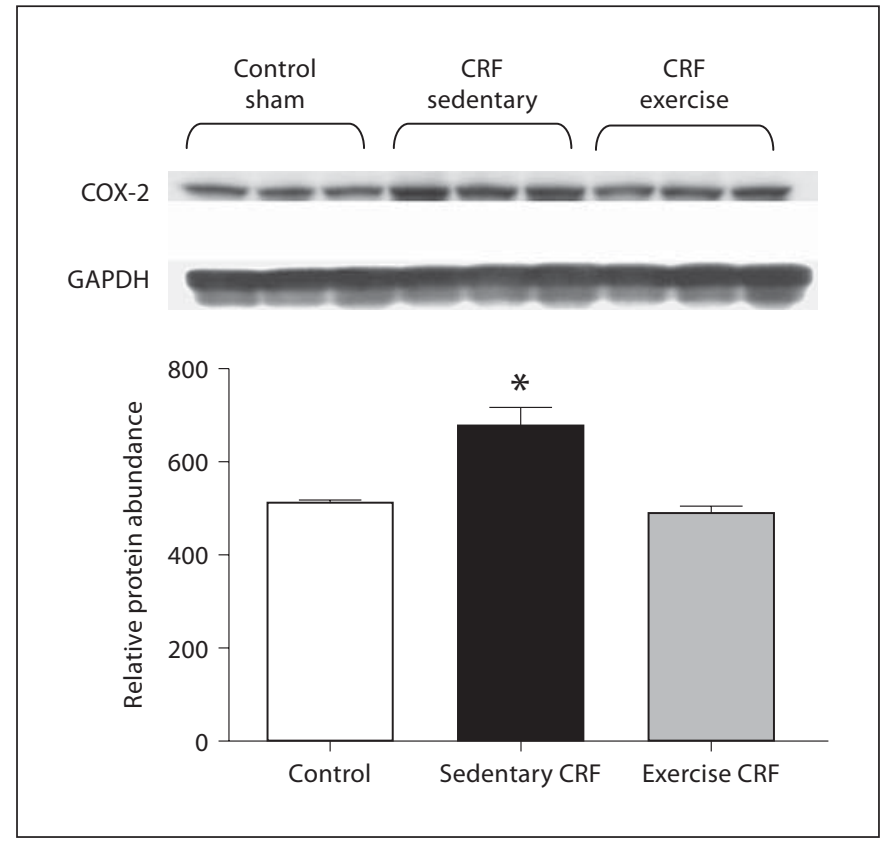

Fig. 5. Representative Western blots and group data depicting COX-2 abundance in the LV of sham-operated (control) group, $5 / 6$ nephrectomized rats housed in regular cages (sedentary CRF) and 5/6 nephrectomized rats housed in cages equipped with running wheels (exercise CRF group) for 4 weeks. ${ }^{*} \mathrm{p}<0.05$, sedentary CRF versus other groups ( $\mathrm{n}=6$ animals in each subgroup).

Am J Nephrol 2009;29:213-221 


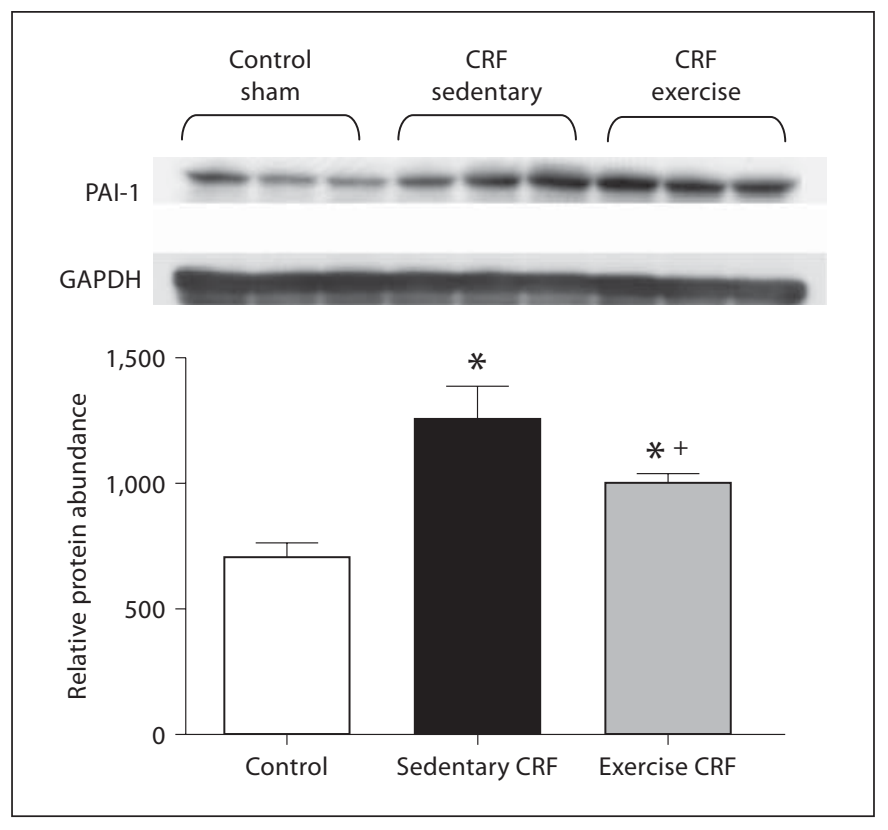

Fig. 6. Representative Western blots and group data depicting PAI-1 abundance in the LV of sham-operated (control) group, 5/6 nephrectomized rats housed in regular cages (sedentary CRF) and 5/6 nephrectomized rats housed in cages equipped with running wheels (exercise CRF group) for 4 weeks. ${ }^{*} \mathrm{p}<0.05$, sedentary CRF versus other groups; ${ }^{+} \mathrm{p}<0.05$, exercise versus sedentary group ( $\mathrm{n}=5$ animals in each group).

\section{COX-2, MCP-1 and PAI-1 Data}

Data are shown in figures $5-7$. The sedentary CRF rats showed significant upregulations of COX-2, MCP-1 and PAI-1 in LV tissue. The exercise regimen normalized MCP-1 and COX-2 expression and attenuated upregulation of PAI-1 in this tissue.

\section{NF- $\kappa$ B Data}

Data are illustrated in figure 8. The sedentary CRF group showed a significant increase in phospho-ІкВ abundance pointing to increased activation of this proinflammatory transcription factor. The exercise regimen resulted in a significant reduction of phospho-ІкB abundance in the cardiac tissue of the CRF animals.

\section{Discussion}

The sedentary 5/6 nephrectomized rats employed in the present study exhibited significant upregulations NAD(P)H oxidase, COX-2, MCP-1 and PAI-1, and activation of NF- $\mathrm{KB}$ in the cardiac tissue. These findings indi-

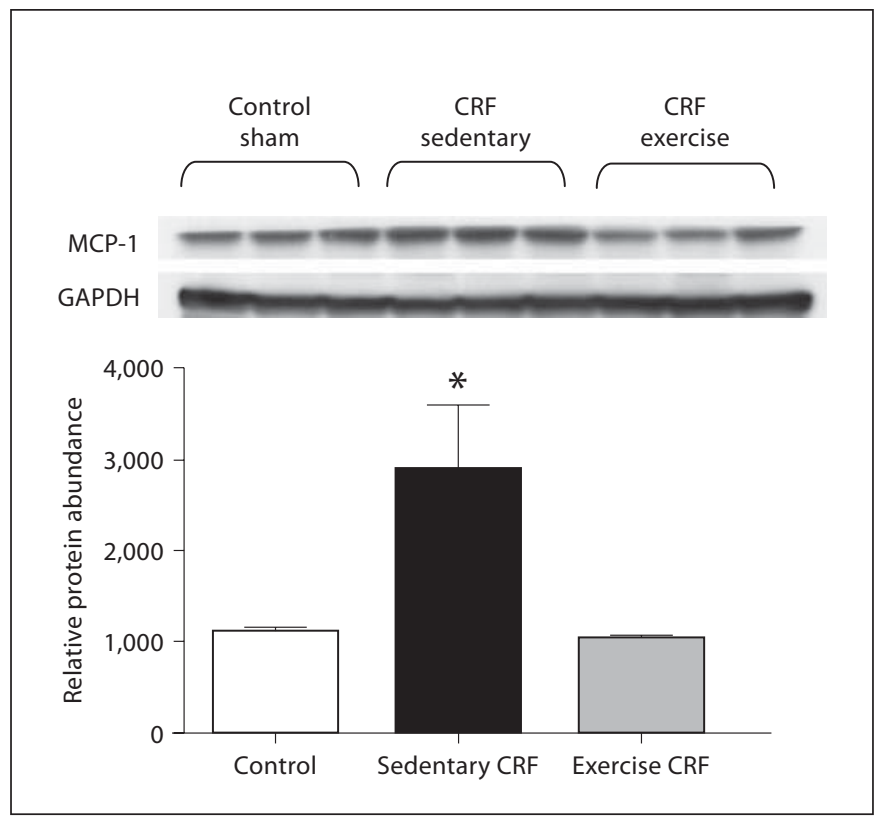

Fig. 7. Representative Western blots and group data depicting MCP-1 abundance in the LV of sham-operated (control) group, $5 / 6$ nephrectomized rats housed in regular cages (sedentary CRF) and $5 / 6$ nephrectomized rats housed in cages equipped with running wheels (exercise CRF group) for 4 weeks. ${ }^{*} \mathrm{p}<0.05$, sedentary CRF versus other groups ( $\mathrm{n}=5$ animals in each group).

cate that renal mass reduction, per se, in the absence of any underlying systemic disease, can heighten oxidative and inflammatory pathways in the heart. Similar changes have been found in the remnant kidney and vascular tissues in this model [33-35].

Despite significant renal insufficiency, the $5 / 6$ nephrectomized animals resumed voluntary exercise. The intensity and duration of exercise seen in the CRF animals was similar to that observed prior to renal mass reduction. This observation suggests that moderate renal insufficiency, per se, may not severely curtail exercise capacity. Moreover, voluntary exercise ameliorated upregulations of cardiac tissue NAD(P)H oxidase, COX-2, MCP-1 and PAI-1 and attenuated NF- $\kappa$ B activation without significantly affecting renal function or arterial pressure. These findings suggest that regular exercise suppresses oxidative and inflammatory pathways in the uremic heart and that the anti-inflammatory and antioxidant actions of exercise in the cardiac tissue are not mediated by modulations of arterial pressure or progression of renal disease.

There is mounting evidence that increased production of ROS in the kidney and cardiovascular tissues contrib- 


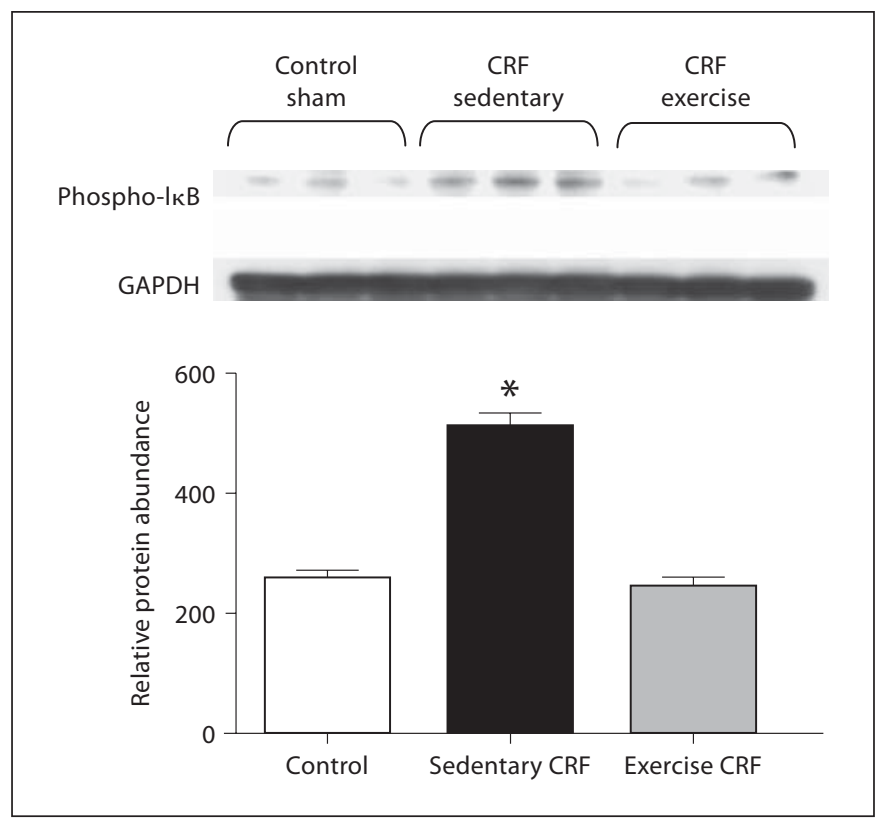

Fig. 8. Representative Western blots and group data depicting phospho-IкB abundance in the LV of sham-operated (control) group, 5/6 nephrectomized rats housed in regular cages (sedentary CRF) and 5/6 nephrectomized rats housed in cages equipped with running wheels (exercise CRF group) for 4 weeks. ${ }^{*} \mathrm{p}<0.05$, CRF versus other groups ( $\mathrm{n}=6$ animals in each subgroup).

utes to HTN, inflammation, cardiovascular remodeling, and atherosclerosis [36, 37] (http://hyper.ahajournals. org/cgi/content/full/47/1/81 - R2-057984). Phagocytic and tissue-specific isoforms of $\mathrm{NAD}(\mathrm{P}) \mathrm{H}$ oxidase are a major source of ROS in the cardiovascular tissues [3841]. $\mathrm{NAD}(\mathrm{P}) \mathrm{H}$ oxidase expression and activity in the renal and cardiovascular tissues are regulated by several factors including mechanical stress, hormones, hypoxia, inflammatory cytokines/chemokines and angiotensin II [42-44]. The sedentary CRF animals employed in the present study showed marked upregulation of $\mathrm{NAD}(\mathrm{P}) \mathrm{H}$ oxidase in the cardiac tissue. $\mathrm{NAD}(\mathrm{P}) \mathrm{H}$ oxidase-derived ROS can contribute to tissue injury and dysfunction by attacking/denaturing structural and functional molecules and by activating redox-sensitive signal transduction pathways and transcription factors such as NF- $\kappa B$ and AP-1 $[45,46]$. For instance, ROS activate NF- $к B$ which, in turn, promotes production of proinflammatory/profibrotic cytokines and chemokines in the affected tissue. In fact, activation of NF- $\kappa \mathrm{B}$ (as evidenced by increased phospho-IкB) in the cardiac tissues of our sedentary CRF rats was accompanied by upregulations of car- diac tissue MCP-1 and PAI-1 which play a major role in the pathogenesis of atherosclerosis and CVD [47].

Cycloxygenases catalyze the conversion of polyunsaturated fatty acids to a family of biologically active lipids such as prostaglandins, thromboxanes, and leukotrienes. These products participate in a wide array of physiological and pathological processes such as inflammation, oxidative reactions, cell growth, vascular permeability, and regulation of local and systemic hemodynamics among others [48-50]. COX-2 abundance was significantly elevated in the hearts of our sedentary CRF animals.

Voluntary exercise for 4 weeks attenuated gp91 ${ }^{\text {phox }}$, NOX-4, MCP-1, PAI-1, and COX-2 in the hearts of the CRF rats. Using internal mammary artery specimens obtained during coronary bypass surgery, Adams et al. [51] reported significant reductions of $\mathrm{NAD}(\mathrm{P}) \mathrm{H}$ oxidase expression and a marked improvement of endothelium-dependent vasorelaxation in a group of patients with coronary artery disease enrolled in a 4-week exercise training program. The favorable response to exercise training reported in the mammary arteries of patients with coronary artery disease parallel the results observed in the hearts of uremic animals employed in the present study.

In conclusion, $\mathrm{CRF}$ results in NF- $\kappa \mathrm{B}$ activation, and upregulations of $\mathrm{NAD}(\mathrm{P}) \mathrm{H}$ oxidase, $\mathrm{COX}-2, \mathrm{MCP}-1$, and PAI-1 in the cardiac tissue. Voluntary wheel running exercise for 4 weeks reversed or attenuated these abnormalities. Although regular exercise resulted in LV hypertrophy, this was due to an adaptive rise in myofibrillar proteins as opposed to the pathological hypertrophy which is due to myocardial fibrosis. These observations point to the potential cardiovascular benefit of exercise in renal insufficiency.

\section{Acknowledgments}

The authors thank Paul Bodell, Phuc Tran, Alvin Yu, Jasleen Saini, Rudy Senstad, Tiffany Yu, Julianne Lynn, Phillip Bucur, Sandy Liu, and Nkiruka Ojukwv for their technical support. This work was funded, in part, by the National Institutes of Health (RO1-HL0792-04 to N.D.V. and NIH P01HD048721, Project 1 to G.R.A.) 


\section{References}

1 Weiner DE, Tighiouart H, Amin MG, Stark PC, MacLeod B, Griffith JL, Salem DN, Levey AS, Sarnak MJ: Chronic kidney disease as a risk factor for cardiovascular disease and all-cause mortality: a pooled analysis of community-based studies. J Am Soc Nephrol 2004;15:1307-1315.

$\checkmark 2$ Go AS, Chertow GM, Fan D, McCulloch CE, Hsu CY: Chronic kidney disease and the risks of death, cardiovascular events, and hospitalization. N Engl J Med 2004;351: 1296-1305.

3 Himmelfarb J, Stenvinkel P, Ikizler TA, Hakim RM: The elephant in uremia: oxidative stress as a unifying concept of cardiovascular disease in uremia. Kidney Int 2002;62: 1524-1538.

4 Vaziri ND: Oxidative stress in uremia: nature, mechanisms and potential consequences. Semin Nephrol 2004;24:469-473.

5 Vaziri ND: Roles of oxidative stress and antioxidant therapy in chronic renal disease and hypertension. Curr Opin Nephrol Hypertens 2004;13:93-99.

-6 Stenvinkel P, Alvestrand A: Inflammation in end-stage renal disease: sources, consequences, and therapy. Semin Dial 2002;15: 329-337.

7 Kaysen GA: Inflammation: cause of vascular disease and malnutrition in dialysis patients. Semin Nephrol 2004;24:431-436.

$\checkmark 8$ Vaziri ND: Effect of chronic renal failure on nitric oxide metabolism. Am J Kidney Dis 2001;38:574-579.

-9 Baylis C: Arginine, arginine analogs and nitric oxide production in chronic kidney disease. Nat Clin Pract Nephrol 2006;2:209220.

- 10 Goncalves AR, Fujihara CK, Mattar AL, Malheiros DM, Noronha Ide L, de Nucci G, Zatz R: Renal expression of COX-2, ANG II, and AT1 receptor in remnant kidney: strong renoprotection by therapy with losartan and a nonsteroidal anti-inflammatory. Am J Physiol Renal Physiol 2004;286:F945-F954.

11 Vaziri ND: Dyslipidemia of chronic renal failure: the nature, mechanisms and potential consequences. Am J Physiol Renal Physiol 2006;290:F262-F272.

12 Gill JM, Malkova D: Physical activity, fitness and cardiovascular disease risk in adults: interactions with insulin resistance and obesity. Clin Sci (Lond) 2006;110:409-425.

13 Warburton DE, Nicol CW, Bredin SS: Health benefits of physical activity: the evidence. CMAJ 2006;174:804-809.

14 Oscai LB, Patterson JA, Bogard DL, Beck RJ, Rothermel BL: Normalization of serum triglycerides and lipoprotein electrophoretic patterns by exercise. Am J Cardiol 1972;30: 775-780.
15 Roberts CK, Vaziri ND, Barnard RJ: Effect of diet and exercise intervention on blood pressure, insulin, oxidative stress and nitric oxide availability. Circulation 2002;106:25302532.

16 Roberts CK, Won D, Pruthi S, Kurtovic S, Sindhu RK, Vaziri ND, Barnard RJ: Effect of a short-term diet and exercise intervention on oxidative stress, inflammation, MMP-9 and monocyte chemotactic activity in men with metabolic syndrome. J Appl Physiol 2006;100:1657-1665.

17 Whelton SP, Chin A, Xin X, He J: Effect of aerobic exercise on blood pressure: a metaanalysis of randomized, controlled trials. Ann Intern Med 2002;136:493-503.

18 Maiorana AG, O’Driscoll C, Cheetham L, Dembo K, Stanton C, Goodman R, Taylor R, Green D: The effect of combined aerobic and resistance exercise training on vascular function in type 2 diabetes. J Am Coll Cardiol 2001;38:860-866.

19 Maiorana A, O’Driscoll G, Dembo L, Cheetham C, Goodman C, Taylor R, Green D: Effect of aerobic and resistance exercise training on vascular function in heart failure. Am J Physiol 2000;279:H1999-H2005.

-20 Varady KA, Jones PJ: Combination diet and exercise interventions for the treatment of dyslipidemia: an effective preliminary strategy to lower cholesterol levels? J Nutr 2005; 135:1829-1835.

21 Roberts CK, Won D, Pruthi S, Kurtovic S, Sindhu RK, Vaziri ND, Barnard RJ: Effect of a short-term diet and exercise intervention on oxidative stress, inflammation, MMP-9 and monocyte chemotactic activity in men with metabolic syndrome. J Appl Physiol 2006;100:1657-1665.

22 Kingwell BA: Nitric oxide-mediated metabolic regulation during exercise: effects of training in health and cardiovascular disease. FASEB J 2000;14:1685-1696.

23 Higashi Y, Yoshizumi M: Exercise and endothelial function: role of endothelium-derived nitric oxide and oxidative stress in healthy subjects and hypertensive patients. Pharmacol Ther 2004;102:87-96.

24 Kojda G, Hambrecht R: Molecular mechanisms of vascular adaptations to exercise. Physical activity as an effective antioxidant therapy? Cardiovasc Res 2005;67:187-197.

25 Vaziri ND, Ni Z, Wang XQ, Oveisi F, Zhou $\mathrm{XJ}$ : Downregulation of nitric oxide synthase in chronic renal insufficiency: role of excess PTH. Am J Physiol Renal Physiol 1998;274: F642-F649.

26 Gonick HC, Ding Y, Bondy SC, Ni Z, Vaziri ND: Lead-induced hypertension. Interplay of nitric oxide and reactive oxygen species. Hypertension 1997;30:1487-1492.
27 Xu Z, Lanting L, Vaziri ND, Li Z, Sepassi L, Rodriguez-Iturbe B, Natarajan R: Upregulation of Ang II type I receptor, inflammatory mediators and enzymes of arachidonate metabolism in obese Zucker rat kidney: reversal by Ang II type I receptor blockade. Circulation 2005;111:1962-1969.

28 Adams GR, Zhan CD, Haddad F, Vaziri ND: Voluntary exercise during chronic renal failure in rats. Med Sci Sports Exerc 2005;37: 557-562.

-29 Scharhag J, Schneider G, Urhausen A, Rochette V, Kramann B, Kindermann W: Athlete's heart: right and left ventricular mass and function in male endurance athletes and untrained individuals determined by magnetic resonance imaging. J Am Coll Cardiol 2002;40:1856-1863.

30 Urhausen A, Kindermann W: Sports-specific adaptations and differentiation of the athlete's heart. Sports Med 1999;28:237-244.

31 Amann K, Tyralla K: Cardiovascular changes in chronic renal failure - pathogenesis and therapy. Clin Nephrol 2002;1:S62-S72.

32 Pessina AC, Sacchetto A, Rossi GP: Left ventricular anatomy and function in primary aldosteronism and renovascular hypertension. Adv Exp Med Biol 1997;432:63-69.

33 Vaziri ND, Dicus M, Ho N, Sindhu R: Oxidative stress and dysregulation of superoxide dismutase and NAD(P)H oxidase in renal insufficiency. Kidney Int 2003;63:179-185.

34 Vaziri ND, Oveisi F, Ding Y: Role of increased oxygen free radical activity in the pathogenesis of uremic hypertension. Kidney Int 1998;53:1748-1754.

35 Vaziri ND, Bai Y, Ni Z, Quiroz Y, RodriguezIturbe $\mathrm{B}$ : Intra-renal angiotensin $\mathrm{II}_{\mathrm{A}} \mathrm{AT}_{1}$ receptor, oxidative stress, inflammation and progressive injury in renal mass reduction. J Pharmacol Exp Ther 2007;323:85-93.

-36 Schulman IH, Zhou MS, Raij L: Nitric oxide, angiotensin II, and reactive oxygen species in hypertension and atherogenesis. Curr Hypertens Rep 2005;7:61-67.

37 Vaziri ND, Rodriguez-Iturbe B: Mechanisms of disease: oxidative stress and inflammation in the pathogenesis of hypertension. Nat Clin Pract Nephrol 2006;2:582-593.

38 Lassenge B, Clempus RE: Vascular NAD (P)H oxidases: specific features, expression, and regulation. Am J Physiol 2003;285:R277R297.

39 Taniyama Y, Griendling KK: Reactive oxygen species in the vasculature: molecular and cellular mechanisms. Hypertension 2003;42:1075-1081.

40 Bayraktutan U, Blayney L, Shah AM: Molecular characterization and localization of the $\mathrm{NAD}(\mathrm{P}) \mathrm{H}$ oxidase components gp91-phox and p22-phox in endothelial cells. Arterioscler Thromb Vasc Biol 2000;20:1903-1911. 
-41 Wang HD, Xu S, Johns DG, Du Y, Quinn MT, Cayatte AJ, Cohen RA: Role of NADPH oxidase in the vascular hypertrophic and oxidative stress response to angiotensin II in mice. Circ Res 2001;88:947-953.

- 42 Seshiah PN, Weber DS, Rocic P, Valppu L, Taniyama Y, Griendling KK: Angiotensin II stimulation of $\mathrm{NAD}(\mathrm{P}) \mathrm{H}$ oxidase activity: upstream mediators. Circ Res 2002;91:406413.

-43 Touyz RM, Chen X, Tabet F, Yao G, He G, Quinn MT, Pagano PJ, Schiffrin EL: Expression of a functionally active gp91phox-containing neutrophil-type $\mathrm{NAD}(\mathrm{P}) \mathrm{H}$ oxidase in smooth muscle cells from human resistance arteries: regulation by angiotensin II. Circ Res 2002;90:1205-1213.
4 Griendling KK, Sorescu D, Ushio-Fukai M: $\mathrm{NAD}(\mathrm{P}) \mathrm{H}$ oxidase: role in cardiovascular biology and disease. Circ Res 2000;86:494501.

-45 Los M, Dröge W, Stricker K, Baeuerle PA, Schulze-Osthoff K: Hydrogen peroxide as a potent activator of T lymphocyte functions. Eur J Immunol 1995;25:159-165.

46 Sen CK: Antioxidant and redox regulation of cellular signaling: introduction. Med Sci Sports Exerc 2001;33:368-370.

47 Zhou JL: Monocyte chemoattractant protein-1: a key mediator of angiotensin II-induced target organ damage in hypertensive heart disease? J Hypertens 2004;22:451454.

48 Reddy MA, Adler SG, Kim YS, Lanting L, Rossi JJ, Kang SW, Nadler JL, Shahed A, Natarajan R: Interaction of MAPK and 12-lipoxygenase pathways in growth and matrix protein expression in mesangial cells. Am J Physiol Renal Physiol 2002;283:F985-F994.
49 Kramer BK, Kammer MC, Komhoff M: Renal cyclooxygenase-2 (COX-2): physiological, pathophysiological, and clinical implications. Kidney Blood Press Res 2004;27: 43-62.

50 Fujihara CK, Antunes GR, Mattar AL, Andreoli N, Malheiros DM, Noronha IL, Zatz $\mathrm{R}$ : Cyclooxygenase-2 (COX-2) inhibition limits abnormal COX-2 expression and progressive injury in the remnant kidney. Kidney Int 2003;64:2172-2181.

51 Adams V, Linke A, Kränkel N, Erbs S, Gielen S, Möbius-Winkler S, Gummert JF, Mohr FW, Schuler G, Hambrecht R: Impact of regular physical activity on the NAD(P)H oxidase and angiotensin receptor system in patients with coronary artery disease. Circulation 2005;111:555-562. 